\title{
Antioxidant Potential of Selected Medicinal Plants of Trans- Himalayan Region
}

\author{
Suman Tiga ${ }^{1}$, Prabhu Prasad Sarangi ${ }^{2}$, Om Prakash Chaurasia ${ }^{3}$, Bhuvnesh Kumar ${ }^{4}$ \\ 1, 2,3,4 Defence Institute of High Altitude Research \\ Corresponding Author: Email ID: suman@dihar.drdo.in
}

\begin{abstract}
Considering the growing interest in possessing the antioxidant capacity of medicinal plants; an effort has been carried to recognize the effect of antioxidants in different plants of Trans-Himalayan region by using DPPH (1, 1-diphenyl-2-picrylhydrazyl) radical assay, ABTS (2, 2'-azinobis- (3-ethylbenzothiazoline-6-sulfonic acid) diammonium salt assay, FRAP (ferric reducing antioxidant power), total phenolic content (TPC), total flavonol, total proanthoanthocyanidin and total flavonoid content. Extraction of antioxidant compound from plants part was done with $80 \%$ methanol. The inhibitory concentration $\left(\mathrm{IC}_{50}\right)$ in $\mathrm{DPPH}$ ranged from 2.306 to $8.604 \mu \mathrm{g} / \mathrm{mg}$. $\left(\mathrm{IC}_{50}\right)$ in ABTS ranged from 1.38 to $7 \mu \mathrm{g} / \mathrm{mg}$ and $\mathrm{FRAP}$ ranged from 102.66 to $385.76 \mathrm{FeSO}_{4} .7 \mathrm{H}_{2} \mathrm{O}$. Highest antioxidant activity was observed in Saussaria lappa. TPC were expressed as gallic acid equivalent (GAE) in $\mu \mathrm{g}$ per mg weight. Total flavonol, total proanthoanthocyanidin and total flavonoid content were expressed as $\mu \mathrm{g}$ of quercetin equivalent per milligram of dry weight. Highest

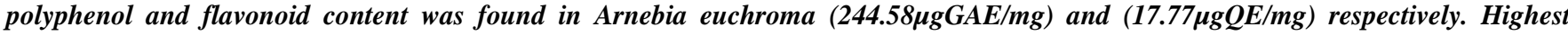
flavonol content was found in Inula racemose $(70 \mu g Q E / m g)$ and proanthocyanidin content was highest in $R . w e b b a n i u m$

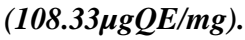

Keywords: Antioxidant potential, Polyphenol, Medicinal plant, Radical scavenger, Trans- Himalayan

\section{Introduction}

Recently there has been an emerging interest globally for identification of antioxidant compounds which are of pharmaceutical and nutraceuticals importance which can be used in preventive medicine and the food industry. Antioxidant activity exhibited by plants might be due to their phenol compounds [1]. Antioxidant plays a vital role by preventing from oxidative damage due to free radical present in the body. A free radical is an atom, molecule or anion that contains one or more unpaired electrons and which is more reactive than their parent species. Free radicals which are formed in the body can realize oxygenation or reduction reactions that damage many biological molecule and cause food rancid [2]. Plants produce significant amount of antioxidants compounds to prevent against the oxidative stress caused by free radicals and nascent oxygen and thus they represent a potential source of new compounds with antioxidant activity. The use of various artificial antioxidants such as butylated hydroxy toluene (BHT), butylated hydroxy anisole (BHA), gallic acid tertiary and butylated hydroquinon have been reported to cause several negative health effects [3], [4]. Therefore, strong restrictions have been made on their application and there is an erg to substitute them with naturally occurring antioxidants. The increasing demand quest for natural antioxidants for pharmaceuticals, nutraceuticals and cosmetic uses has become one of the major industrial and scientific research challenges. These create an environmental issue of the extinction of many of the medicinal plant species due to indiscriminate harvesting in large quantity from the wild to meet the increasing demand for the crude drugs. As a result of this and lack of cultivation many of the medicinal plant species has been reported threatened species. Efforts to gain knowledge regarding the antioxidants power from plants and to know their potential are therefore on the increase. The traditional herbal medicine in India and across the world has its own importance in human health care and prevention of many diseases. One of the oldest medical systems in the world that provides potential leads is ayurveda that find potent and therapeutically useful compounds from plants. The TransHimalayan region is the land of several medicinal plants. Some of the medicinal plants like Saussaria lappa, Rheum webbanium, Arnebia euchroma, Inula racemosa are used as healing sources, which thereby helps in the emerging area of antioxidant research of medicinal plants. Their rhizomes, stems, leaves, bark, are important parts which have medicinal properties. The root powder of Inula racemosa is used for hypoglycemic and hypocholesterolemic in human subjects and also considered specific for cough, dyspnea, asthma, pleurisy, tuberculosis and chest pain especially pre cordial pain. Rheum webbanium roots are rich sources of drugs rhein, emodin and rutin which are used as laxative, tonic and purgative. The powder is sprinkled on ulcers and wounds for quick healing and also is used for cleaning teeth [5]. Another medicinal herb Saussurea lappa its principal constituents, costunolide dehydrocostus used as anti-ulcer, anti-carcinogenesis. Another potent plant is Arnebia ecrhoma; it has have been reported to have antiinflammatory, antimicrobial and anti-tumor activities and thus considered as one of the important compound for potentially medicinal use [6]. To the best of the knowledge, there is no report on these antioxidant properties in methanolic extracts of the mentioned species in the literature. Thus, the present investigation focuses (i) in vitro antioxidant activity profiles of these plant extracts by using 2,2-diphenyl-1-picrylhydrazyl (DPPH) radical scavenging assay, 2,2'-azinobis- (3-ethylbenzothiazoline-6-sulfonic acid) (ABTS) and ferric reducing antioxidant power (FRAP) (ii) total phenolic compounds content of the plant extracts as gallic acid equivalents(GAE) and total proanthocyanidin, total flavonol and total flavanoid compound as quercetin equivalent(QE). 


\section{Materials and Methods}

\section{Chemicals}

2,4,6-tripyridyl-s-triazine (TPTZ), sodium carbonate $\left(\mathrm{Na}_{2} \mathrm{CO}_{3}\right)$, ferrous sulphate $\left(\mathrm{FeSO}_{4} \cdot 7 \mathrm{H}_{2} \mathrm{O}\right)$, aluminium chloride $\left(\mathrm{AlCl}_{3}\right)$, Folin-Ciocalteu's phenol reagent, gallic acid anhydrous, 1-diphenyl-2-picrylhydrazyl radical (DPPH), naphthyethylenediamine dihydrochloride, sodium acetate $\left(\mathrm{C}_{2} \mathrm{H}_{3} \mathrm{NaO}_{2}\right)$, potassium persulfate $\left(\mathrm{K}_{2} \mathrm{~S}_{2} \mathrm{O}_{8}\right)$, glacial acetic acid, butylated hydroxytoluene (BHT), ascorbic acid, 2,2'-azinobis- (3-ethylbenzothiazoline-6-sulfonic acid) diammonium salt (ABTS), quercetin, vanillin, hydrochloric acid, n-hexane, chloroform, ethanol, potassium chloride $(\mathrm{KCl})$, ferric chloride $\left(\mathrm{FeCl}_{3} \cdot 6 \mathrm{H}_{2} \mathrm{O}\right)$, egg yolk emulsion, sulfanilic acid $\left(\mathrm{C}_{6} \mathrm{H}_{7} \mathrm{NO}_{3} \mathrm{~S}\right)$, sulphuric acid, methanol and sodium carbonate. All other chemicals used including solvents were of analytical grade.

\section{Plant materials}

The plants were collected from medicinal garden, DIHAR, Leh.

\section{Preparation of extract}

Fresh roots from the plants were shade dried and milled to fine powder using a mechanical grinder. Dried powder plant material $(75 \mathrm{~g})$ root was taken in thimble and was extracted with $600 \mathrm{ml}, 80 \%$ methanol separately for 24 hrs by soxhlet apparatus. The extract were concentrated by rotary evaporator under reduce pressure at $40^{\circ} \mathrm{C}$. Further the concentrated extract was oven dried to obtain dry power form of the crude extract and these were stored in $-20^{\circ} \mathrm{C}$ for future analysis.

\section{Procedure for determination of antioxidant}

\section{Determination of 1, 1- Diphenyl-2-picrylhydrazyl (DPPH) Assay}

The effect of different extract on DPPH radical was determined using method described previously [7]. A solution of $0.135 \mathrm{mM}$ DPPH in methanol was prepared and $100 \mu \mathrm{l}$ of the working solution was mixed with $100 \mu \mathrm{l}$ of the different extract. The concentration of plant extracts was ranged from 5 to $500 \mu \mathrm{g} / \mathrm{ml}$. The reaction mixture was vortexed vigoursly and rested in the dark for 30 minute at room temperature. The absorbance of the mixture was measured spectrophotometrically at $517 \mathrm{~nm}$. Ascorbic acid (AA) was used as standards. The ability to scavenge DPPH radical was calculated by the following equation:

DPPH radical scavenging capacity $(\%)=\left[\left(\mathrm{Abs}_{\text {control }}-\mathrm{Abs}\right.\right.$ sample) $/\left(\right.$ Abs $\left.\left._{\text {control }}\right)\right] \times 100$

Where, Abs control is the absorbance of DPPH radical and methanol;

Abs sample is the absorbance of DPPH radical with sample extract or standard. The $\left(\mathrm{IC}_{50}\right)$, half maximal inhibitory concentration for scavengers (radical scavenging concentration 50 or $\mathrm{RSa}_{50}$ ), define as the amount of antioxidant required to decrease the initial DPPH concentration by $50 \%$, termed as efficiency concentration $\left(\mathrm{EC}_{50}\right)$. The effectiveness of antioxidant and radical scavenging capacity demonstrated as antiradical power (ARP) were calculated [8], [9], [10], [11]. The $\mathrm{RSa}_{50}$ value was determined by plotting the scavenging capacity against the logarithm of sample concentration. The $\mathrm{EC}_{50}$ was calculated from the following formula: $\mathrm{EC}_{50}=\mathrm{IC}_{50} /[\mathrm{DPPH}]$ in $\mu \mathrm{g} / \mathrm{ml}$ :

The ARP was also determined as follows: $\mathrm{ARP}=1 /\left(\mathrm{EC}_{50} \mathrm{X}\right.$ 100)

The results were expressed as ascorbic acid equivalent antioxidant capacity (AEAC) [12] using the following equation: $\mathrm{AEAC}=\left(\mathrm{IC}_{50 \text { (AA) }} / \mathrm{IC}_{50 \text { (sample) }}\right) \times 10^{5}$

\section{Determination of ABTS Radical Scavenging Assay}

The ABTS assay was performed as described by Pellegrini and proteggente [13]. The stock solutions containing $2.4 \mathrm{mM}$ potassium persulfate(PPS) solution and $7 \mathrm{mM}$ ABTS solution were prepared. The working solution was prepared by mixing equal quantities of the two stock solutions and rested them for 12 hours at room temperature in dark for its reaction. Thereafter the solution was diluted by the addition of $1 \mathrm{ml} \mathrm{ABTS}{ }^{+}$solution with $60 \mathrm{ml}$ of methanol to obtain an absorbance of $0.706 \pm 0.001$ units at $734 \mathrm{~nm}$ using spectrophotometer. The concentration of plant extracts was ranged from 5 to $500 \mu \mathrm{g} / \mathrm{ml}$. Plant extracts $(100 \mu \mathrm{l})$ and $100 \mu \mathrm{l}$ of the $\mathrm{ABTS}^{+}$solution was allowed to react and the absorbance was taken at $734 \mathrm{~nm}$ after 7 min incubation at $25^{\circ} \mathrm{C}$ in 96 well plate. The $\mathrm{ABTS}^{+}$scavenging capacity of the extracts was compared with that of BHT. The radical scavenging percentage of different extract was calculated as follows:

ABTS radical scavenging capacity $(\%)=\left[\left(\mathrm{Abs}_{\text {control }}-\mathrm{Abs}\right.\right.$ sample $)] /\left(\right.$ Abs $\left.\left._{\text {control }}\right)\right] \times 100$

Where, Abs control is the absorbance of ABTS radical + methanol; Abs sample is the absorbance of ABTS radical with standard or sample extract. The $\mathrm{RSa}_{50}, \mathrm{EC}_{50}$, ARP and AEAC values were also calculated as described in the previous section.

\section{Determination of Ferric Reducing Antioxidant Power} (FRAP) Assay

The reducing power of ferric ions by different plant extract was determined using FRAP assay [14]. An antioxidant capable of donating a single electron to the ferric-TPTZ $\left(\mathrm{Fe}^{+3}-\mathrm{TPTZ}\right)$ complex would cause the reduction of this complex into the blue ferrous-TPTZ $\left(\mathrm{Fe}^{+2}\right.$-TPTZ) complex which absorbs strongly at $593 \mathrm{~nm}$. The antioxidant potential of the different extract was determined based on a calibration curve plotted using $\mathrm{FeSO}_{4}$ concentration ranging from $(20-100 \mu \mathrm{g} / \mathrm{ml})$.

\section{Determination of Antioxidant Compound Concentration.}

\section{Determination of Total Phenol Content}

Total polyphenolic in different extract content was determined using Folin- Ciocalteu colorimetric method as described by Ohlander and Jeppsson[15]. The phytococktail extracts $(10 \mu \mathrm{l})$ was mixed with $20 \mu \mathrm{l}$ of Folin- Ciocalteu reagent and $200 \mu \mathrm{l}$ of $\mathrm{H}_{2} \mathrm{O}$, and incubated at room temperature for $3 \mathrm{~min}$. Thereby following the addition of $100 \mu 1$ of $20 \%$ sodium carbonate to the mixture. Total polyphenol was determined after 1 hours of incubation at room temperature. The absorbance of the resulting blue colour was measured at $765 \mathrm{~nm}$. Quantification was done with respect to the standard curve of gallic acid. The total 
polyphenol content was expressed as gallic acid equivalent (GAE).

\section{Determination of Total Flavonoid Content}

Estimation of total flavonoid in the methanol extracts was carried out using the previous method [16]. 100 $\mu 1$ of sample and $100 \mu \mathrm{l}$ of $2 \% \mathrm{AlCl}_{3}$ ethanol solution were mixed together. The prepared test solution was incubated for 1 hour at room temperature. The absorbance of the test solution was measured at $420 \mathrm{~nm}$. Total flavonoid content was calculated as quercetin equivalent (QE) using the derived equation based on the calibration curve: $y=0.002 x+0.0998, r^{2}=0.9704$, where ' $y$ ' was absorbance and ' $x$ ' was QE (mg of extract) at a final concentration of $100 \mu \mathrm{g} / \mathrm{ml}$.

\section{Determination of Total Flavonol Content}

Total flavonol in the extracts was determined by the method described previously [17]. $100 \mu \mathrm{l}$ of test extract, $150 \mu \mathrm{l}$ $(50 \mathrm{~g} / \mathrm{l})$ sodium acetate solutions and $100 \mu \mathrm{l}$ of $2 \% \mathrm{AlCl}_{3}$ ethanol were added. The test mixture was mixed properly. The test mixture was rested for 2.5 hours at $20^{\circ} \mathrm{C}$ and absorbance at $440 \mathrm{~nm}$ was taken. Total flavonol content was estimated as quercetin equivalent (QE) using the calibration curve: $y=0.0007 x+0.077, \quad r^{2}=0.9819$, where ' $y$ ' was absorbance and ' $\mathrm{x}$ ' was $\mathrm{QE}$ (mg of extract) at a final concentration of $100 \mu \mathrm{g} / \mathrm{ml}$.

\section{Determination of Total Proanthocyanidin Content}

Total proanthocyanidin test was determined by vanillin- $\mathrm{HCl}$ assay with minor modification [18]. (1\%) Vanillin reagent was prepared by mixing methanol and incubated at $30^{\circ} \mathrm{C}$ before use. (8\%) $\mathrm{HCl}$ solution in methanol was prepared. The working reagent was prepared by mixing equal part of $8 \% \mathrm{HCl}$ solution and $1 \%$ vanillin solution. The reaction mixture contained and plant extracts $(20 \mu \mathrm{l})$ and working vanillin reagent $(100 \mu \mathrm{l})$. The absorbance at $500 \mathrm{~nm}$ was taken after $20 \mathrm{~min}$ at $30^{\circ} \mathrm{C}$. Total proanthocyanidin content was expressed as quercetin equivalent $\mathrm{QE}$ using calibration curve: $\mathrm{y}=0.0003 \mathrm{x}+0.0435, \quad \mathrm{r}^{2}=0.9847$, where ' $\mathrm{y}$ ' was absorbance and ' $\mathrm{x}$ ' was $\mathrm{QE}$ (mg of extract) at a final concentration of $100 \mu \mathrm{g} / \mathrm{ml}$.

\section{Statistical Analysis}

All the measurement was done in triplicate. The results are expressed as the mean value \pm S.E.M. Statistical analysis was performed using ANOVA, Duncan's multiple range tests was performed. Statistical significance was set at $p<$ 0.05 .

\section{Result \& Discussion}

To determine antioxidant activities of Inula racemosa, Rheium webbanium, Arnebia echroma and Saussaria lappa root were dried and sequentially extracted with $80 \%$ methanol in a soxhlet apparatus. Table 1 shows the extraction yields for the plant extracts. The Percentage yield of Methanolic extracts varied from $(1.77 \%$ to $51.65 \%)$. S.lappa produced the highest yield $(51.65 \%)$ followed by Rheium webannium $(31.76 \%)$ and Inula racemosa $(6.4 \%)$ and lowest produced in A.euchroma (1.77\%). These entire fractions were used to evaluate their in vitro antioxidant potential.

Table 1: Percentage yield of Methanol extracts of medicinal herb

\begin{tabular}{cccc}
\hline Sources of extract & $\begin{array}{c}\text { Weight of the } \\
\text { plant powder }(\mathrm{g})\end{array}$ & $\begin{array}{c}\text { Weight of the } \\
\text { crude extract } \\
\text { obtained }(\mathrm{g})\end{array}$ & $\begin{array}{c}\text { Percentage } \\
\text { of yield (\%) }\end{array}$ \\
\hline Inula racemosa & 75 & 4.8 & 6.4 \\
Saussaria lappa & 75 & 38.74 & 51.65 \\
$\quad \begin{array}{c}\text { Rheium } \\
\text { webannium }\end{array}$ & 75 & 23.82 & 31.76 \\
$\begin{array}{c}\text { Arnebia euchroma } \\
\text { S }\end{array}$ & 75 & 1.33 & 1.77 \\
\hline
\end{tabular}

\section{Determination of Antioxidant Capacity}

The antioxidant activity of the wild herbs was analysed using in vitro methods such as DPPH radical scavenging, ABTS radical cation scavenging activity and ferric reducing antioxidant power (FRAP) activity.

\section{DPPH scavenging activity}

Antioxidants compound in extract was react with DPPH, which is a stable free radical and is reduced to the DPPH-H and as result of which the absorbance's starts decreasing from the DPPH radical to the DPPH-H form. The degree of discoloration marks the scavenging potential activity of the antioxidant compounds or extracts in terms of hydrogen donating ability [19]. Radical scavenging activity of the crude extracts from selected four high altitude medicinal plants was quantitatively determined using a DPPH assay as presented in table 2 . The dosage of extract is expressed in $\mu \mathrm{g}$ of dry weight of the extract (compound) per ml of the assay mixture. The free radical scavenging capacity of the phytococktail methanol extract of different medicinal herb was compared with ascorbic acid with their ability to scavenge DPPH radical. The free average radicalscavenging activity ranges from $(39.56 \%)$ to $(68.94 \%)$ (Table 2). The methanolic root extract of Saussaria lappa (68.94\%) has maximum radical scavenging activity followed by Arnebia euchroma (67.17\%), Rheum webbanium $(46.26 \%)$, and least radical scavenging activity was found in Inula racemosa $(39.56 \%)$. The antioxidant activity of the plants varied considerably in terms of $\mathrm{IC}_{50}$ value (Table 2). The $\mathrm{IC}_{50}$ value for each fraction, defined as the concentration at which 50 percent inhibition of free radicals has been occurred. The $\mathrm{IC}_{50}$ has been determined and tabulated (Table 2). Since $\mathrm{IC}_{50}$ is a measurement of inhibitory concentration, a lower value; reflect greater antioxidant activity of the fraction. The antioxidant potential of an extract is inversely proportional to $\mathrm{IC}_{50}$ value, which was calculated from the linear regression of the percentage antioxidant activity versus, extracts concentrations. The free radical-scavenging activity in terms of $\mathrm{IC}_{50}$ values ranging from $(2.306 \mu \mathrm{g} / \mathrm{mg})$ to $(8.604 \mu \mathrm{g} / \mathrm{mg})$ among the medicinal herb. It was also observed that the DPPH activity of wild herb extract increases in a dose-dependent manner. The various concentrations of the fractions which showed radical scavenging activity greater than $60 \%$ were found to be significant $(p<0.05)$. 
International Journal of Science and Research (IJSR)

ISSN (Online): 2319-7064

Table 2: DPPH radical scavenging activity of methanol extract of medicinal plant

\begin{tabular}{ccccc}
\hline \multicolumn{5}{c}{ Radical Scavenging Capacity (\%) } \\
\hline Conc. $(\mu \mathrm{g} / \mathrm{ml})$ & I.racemosa & S. lappa & R. webbanium & A. euchroma \\
\hline 5 & $21.74 \pm 1.13 \mathrm{a}$ & $33.33 \pm 1.53 \mathrm{a}$ & $6.91 \pm 1.4 \mathrm{a}$ & $27.43 \pm 1.83 \mathrm{a}$ \\
10 & $24.26 \pm 1.9 \mathrm{ab}$ & $39.67 \pm 0.58 \mathrm{~b}$ & $11.45 \pm 1.22 \mathrm{ab}$ & $34.70 \pm 2.38 \mathrm{~b}$ \\
20 & $24.26 \pm 0.73 \mathrm{ab}$ & $48.81 \pm 0.87 \mathrm{c}$ & $15.69 \pm 0.71 \mathrm{bc}$ & $55.79 \pm 3.93 \mathrm{c}$ \\
25 & $26.21 \pm 0.38 \mathrm{~b}$ & $62.63 \pm 0.75 \mathrm{~d}$ & $18 \pm 0.76 \mathrm{c}$ & $71.06 \pm 1.5 \mathrm{~d}$ \\
40 & $27.28 \pm 0.19 \mathrm{~b}$ & $69.33 \pm 0.25 \mathrm{e}$ & $23.25 \pm 3.64 \mathrm{~d}$ & $71.70 \pm 1.26 \mathrm{de}$ \\
50 & $30.60 \pm 1.44 \mathrm{c}$ & $79.99 \pm 1.88 \mathrm{f}$ & $32.97 \pm 1.32 \mathrm{e}$ & $72.21 \pm 1.68 \mathrm{de}$ \\
100 & $33.48 \pm 1.43 \mathrm{~cd}$ & $81.93 \pm 1.93 \mathrm{f}$ & $53.99 \pm 3.31 \mathrm{f}$ & $74.94 \pm 0.99 \mathrm{def}$ \\
125 & $34.34 \pm 0.62 \mathrm{~d}$ & $82.65 \pm 0.69 \mathrm{f}$ & $71.78 \pm 2.01 \mathrm{~g}$ & $78.69 \pm 0.29 \mathrm{efg}$ \\
200 & $44.06 \pm 0.82 \mathrm{e}$ & $82.72 \pm 0.87 \mathrm{f}$ & $78.11 \pm 1.78$ & $78.47 \pm 0.61 \mathrm{efg}$ \\
250 & $55.87 \pm 0.26 \mathrm{f}$ & $82.86 \pm 1.12 \mathrm{f}$ & $79.7 \pm 0.25 \mathrm{~h}$ & $79.41 \pm 3.42 \mathrm{fg}$ \\
400 & $69.18 \pm 1.46 \mathrm{~g}$ & $81.14 \pm 0.8 \mathrm{f}$ & $81.14 \pm 0.85$ & $79.34 \pm 3.5 \mathrm{fg}$ \\
500 & $83.51 \pm 0.8 \mathrm{~h}$ & $82.22 \pm 0.9 \mathrm{f}$ & $82.22 \pm 0.19 \mathrm{~h}$ & $82.29 \pm 0.57 \mathrm{~g}$ \\
MEAN \pm S.E.M & $39.56 \pm 3.22$ & $68.94 \pm 3$ & $46.26 \pm 5.03$ & $67.17 \pm 3$ \\
IC 50 & 8.604 & 2.306 & 6.95 & 2.51 \\
EC 50 & 161.724 & 43.35 & 130.642 & 47.208 \\
ARP & 0.006 & 0.023 & 0.008 & 0.021 \\
AEAC & 117500.81 & 438411.54 & 145464.32 & 402779.68
\end{tabular}

The value means of three replicates \pm standard error mean. The values followed by different alphabets differ significantly when subjected to Duncan's multiple range test at 0.5 subset

\section{ABTS Radical Scavenging Activity}

The ABTS radical scavenging capacity $(\%)$ of methanol extracts of the different medicinal herb has been compared in (Table 3). The extracts scavenged the ABTS radical in a dose dependent manner at concentration of $5-500 \mu \mathrm{g} / \mathrm{ml}$. Average ABTS radical scavenging capacity ranged from (47.54 to $66 \%$ ). Highest radical scavenging activity showed by Saussaria lappa (66\%) followed by Arnebia euchroma
(64.05\%), Rheum webbanium (55.47\%) and least scavenging activity was shown by Inula racemosa $(47.54 \%)$. The medicinal plant having lesser $\mathrm{IC}_{50}$ value has higher antioxidant activity; A. euchroma and S. lappa have the lower value thus exhibiting higher antioxidant activity. The concentrations of the various fractions which showed scavenging activity greater than $60 \%$ were found to be significant $(p<0.5)$.

Table 3: ABTS Radical Scavenging Activity of methanol extra extract of medicinal herb

\begin{tabular}{ccccc}
\hline & & Radical Scavenging Capacity $(\%)$ & \\
\hline Conc. $(\mu \mathrm{g} / \mathrm{ml})$ & I.racemosa & S. lappa & R. webbanium & A. euchroma \\
\hline 5 & $12.37 \pm 2.74 \mathrm{a}$ & $39.83 \pm 0.21 \mathrm{a}$ & $20.54 \pm 0.2 \mathrm{a}$ & $42.77 \pm 1.45 \mathrm{a}$ \\
10 & $23.27 \pm 3.32 \mathrm{~b}$ & $45.49 \pm 0.55 \mathrm{ab}$ & $22.64 \pm 0.36 \mathrm{a}$ & $53.88 \pm 2.36 \mathrm{~b}$ \\
20 & $25.58 \pm 0.21 \mathrm{bc}$ & $51.14 \pm 2.41 \mathrm{bc}$ & $33.54 \pm 0.91 \mathrm{~b}$ & $61.01 \pm 0.72 \mathrm{c}$ \\
25 & $30.4 \pm 1.99 \mathrm{c}$ & $55.97 \pm 0.95 \mathrm{c}$ & $37.94 \pm 1.37 \mathrm{c}$ & $63.10 \pm 0.75 \mathrm{~cd}$ \\
40 & $44.65 \pm 1.31 \mathrm{~d}$ & $63.52 \pm 0.36 \mathrm{~d}$ & $49.48 \pm 0.55 \mathrm{~d}$ & $63.73 \pm 0.55 \mathrm{~cd}$ \\
50 & $46.33 \pm 0.21 \mathrm{~d}$ & $65.82 \pm 1.1 \mathrm{de}$ & $56.39 \pm 0.55 \mathrm{e}$ & $66.67 \pm 0.36 \mathrm{~cd}$ \\
100 & $57.02 \pm 0.21 \mathrm{e}$ & $68.67 \pm 4.95 \mathrm{dc}$ & $67.51 \pm 1.27 \mathrm{f}$ & $68.34 \pm 0.42 \mathrm{~cd}$ \\
125 & $58.28 \pm 1.37 \mathrm{e}$ & $70.23 \pm 3.45 \mathrm{ef}$ & $74.00 \pm 0.55 \mathrm{~g}$ & $68.97 \pm 4.01 \mathrm{~cd}$ \\
200 & $64.15 \pm 0.63 \mathrm{f}$ & $75.26 \pm 2.57 \mathrm{fg}$ & $74.63 \pm 0.21 \mathrm{~g}$ & $69.18 \pm 3.8 \mathrm{~d}$ \\
250 & $68.97 \pm 0.55 \mathrm{~g}$ & $80.08 \pm 1.04 \mathrm{gh}$ & $75.24 \pm 0.22 \mathrm{~g}$ & $70.65 \pm 3.9 \mathrm{~d}$ \\
400 & $69.39 \pm 0.21 \mathrm{~g}$ & $85.74 \pm 0.75 \mathrm{hi}$ & $75.45 \pm 0.02 \mathrm{~g}$ & $70.86 \pm 2.72 \mathrm{~d}$ \\
500 & $70.02 \pm 1.11 \mathrm{~g}$ & $90.14 \pm 0.55 \mathrm{j}$ & $78.2 \pm 0.91 \mathrm{~h}$ & $69.39 \pm 2.36$ \\
MEAN \pm S.E.M & $47.54 \pm 3.31$ & $66 \pm 2.59$ & $55.47 \pm 3.55$ & $64.05 \pm 1.86$ \\
IC 50 & 7.00 & 2.81 & 5.61 & 1.38 \\
EC 50 & 1.82 & 0.732 & 1.46 & 0.36 \\
ARP & 0.55 & 0.13 & 0.69 & 2.79 \\
AEAC & 57143.87 & 142351.28 & 71302.51 & 289860.22
\end{tabular}

The value means of three replicates \pm standard error mean. The values followed by different alphabets differ significantly when subjected to Duncan's multiple range test at 0.5 subset

\section{Ferric Reducing Antioxidant Power (FRAP)}

The reduction of the ferric ions by various root extract was determined using the FRAP assay. Aydemir reported that a significant correlation between reducing power and antioxidant activity [20]. Reducing power of a compound is said to be the indicator of its antioxidant capacity. The results of present study of reducing power of plant part extracts are shown in table 4. A large range values was obtained for ferric reducing activity. The ferric reducing activity in methanolic extracts ranged from (182 $\mathrm{FeSO}_{4} .7 \mathrm{H}_{2} \mathrm{O} \mu \mathrm{g} / \mathrm{ml}$ to $1022 \mathrm{FeSO}_{4} .7 \mathrm{H}_{2} \mathrm{O} \mu \mathrm{g} / \mathrm{ml}$ ) at sample concentration $500 \mu \mathrm{g} / \mathrm{ml}$ (Table 4). Average antioxidant activity was found highest in Saussaria lappa (385.76 
$\left.\mathrm{FeSO}_{4} .7 \mathrm{H}_{2} \mathrm{O} \mu \mathrm{g} / \mathrm{ml}\right)$ followed by Arnebia euchroma (308.52 $\left.\mathrm{FeSO}_{4} .7 \mathrm{H}_{2} \mathrm{O} \mu \mathrm{g} / \mathrm{ml}\right)$, Rheum webbanium (104.96 $\mathrm{FeSO}_{4} \cdot 7 \mathrm{H}_{2} \mathrm{O} \mu \mathrm{g} / \mathrm{ml}$ ), and least radical scavenging activity was observed in Inula racemosa $\left(102.66 \mathrm{FeSO}_{4} .7 \mathrm{H}_{2} \mathrm{O} \mu \mathrm{g} / \mathrm{ml}\right)$ respectively. Higher ferric reducing antioxidant potential with Saussaria lappa; it suggests that the extract contains significantly higher total antioxidant capacity (TAC). The difference in FRAP value between the different concentration (5 to $500 \mu \mathrm{g} / \mathrm{ml}$ ) showing the lowest and highest value was 1- 10 folds in Saussaria lappa. All the extracts showed reducing power in a dose-dependent manner [21]. This highlights the importance of plant species for determining ferric reducing antioxidant potential of root extract from different plant species. Antioxidant activity capacity observed in the above result DPPH, ABTS, FRAP was analogous to each other.

Table 4: FRAP Radical Scavenging Activity of methanol extract of medicinal herb

\begin{tabular}{ccccc}
\hline \multicolumn{5}{c}{ Radical Scavenging Capacity (\%) } \\
\hline I.racemosa & FRAP $\left(\right.$ FeSO $\left._{4} .7 \mathrm{H}_{2} \mathrm{O} \mu \mathrm{g} / \mathrm{ml}\right)$ & A euchroma \\
\hline Conc. $(\mu \mathrm{g} / \mathrm{ml})$ & $76.55 \pm 1.39 \mathrm{a}$ & S. lappa & R. webbanium & $94.6 \pm 1.17 \mathrm{a}$ \\
10 & $80.57 \pm 0.79 \mathrm{ab}$ & $100.11 \pm 0.8 \mathrm{a}$ & $67.82 \pm 0.46 \mathrm{a}$ & $100.8 \pm 2.6 \mathrm{a}$ \\
20 & $83.33 \pm 1.09 \mathrm{~b}$ & $126.9 \pm 0.72 \mathrm{~b}$ & $68.16 \pm 1.51 \mathrm{a}$ & $117.24 \pm 2.78 \mathrm{~b}$ \\
25 & $84.37 \pm 2.12 \mathrm{~b}$ & $156.09 \pm 6.6 \mathrm{c}$ & $71.26 \pm 1.09 \mathrm{abc}$ & $134.48 \pm 2.6 \mathrm{c}$ \\
40 & $86.89 \pm 2.09 \mathrm{bc}$ & $159.88 \pm 2.07 \mathrm{c}$ & $76.78 \pm 0.5 \mathrm{bc}$ & $163.34 \pm 2.95 \mathrm{~d}$ \\
50 & $91.15 \pm 2.99 \mathrm{~cd}$ & $188.16 \pm 1.67 \mathrm{~d}$ & $78.74 \pm 2.59 \mathrm{~cd}$ & $227.24 \pm 2.49 \mathrm{e}$ \\
100 & $92.87 \pm 0.41 \mathrm{~cd}$ & $340.92 \pm 0.98 \mathrm{e}$ & $85.75 \pm 4.51 \mathrm{~d}$ & $231.15 \pm 1.13 \mathrm{e}$ \\
125 & $95.52 \pm 1.05 \mathrm{~d}$ & $388.39 \pm 0.3 \mathrm{f}$ & $105.63 \pm 3.04 \mathrm{e}$ & $298.05 \pm 0.92 \mathrm{f}$ \\
200 & $102.02 \pm 1.91 \mathrm{e}$ & $510.92 \pm 7.2 \mathrm{~g}$ & $110.12 \pm 2.46 \mathrm{e}$ & $400.35 \pm 8.45 \mathrm{~g}$ \\
400 & $118.39 \pm 0.11 \mathrm{f}$ & $592.53 \pm 6.67 \mathrm{~h}$ & $139.31 \pm 0.69 \mathrm{f}$ & $472.18 \pm 6.78 \mathrm{~h}$ \\
500 & $137.7 \pm 3.46 \mathrm{~g}$ & $933.79 \pm 4.14 \mathrm{i}$ & $184.48 \pm 0.71 \mathrm{~g}$ & $667.24 \pm 3.63 \mathrm{i}$ \\
MEAN \pm S.E.M & $182.53 \pm 4.08 \mathrm{~h}$ & $1022.87 \pm 4.78 \mathrm{j}$ & $202.98 \pm 6.39 \mathrm{~h}$ & $795.52 \pm 2.63 \mathrm{j}$
\end{tabular}

The value means of three replicates \pm standard error mean. The values followed by different alphabets differ significantly when subjected to Duncan's multiple range test at 0.5 subset

Table 5: Total phenolic, flavanol, flavonoid, proanthocyanides of methanol extract of medicinal herb

\begin{tabular}{c|cccc}
\hline Sample & $\begin{array}{c}\text { Total polyphenol } \\
(\mu \mathrm{gGAE} / \mathrm{mg} \text { of sample) }\end{array}$ & $\begin{array}{c}\text { Total flavanol } \\
(\mu \mathrm{gQE} / \mathrm{mg} \text { of sample) }\end{array}$ & $\begin{array}{c}\text { Total flavonoid } \\
(\mu \mathrm{gQE} / \mathrm{mg} \text { of sample) }\end{array}$ & $\begin{array}{c}\text { Total proanthocyanidin } \\
\mu \mathrm{gQE} / \mathrm{mg} \text { of sample }\end{array}$ \\
\hline Inula racemosa & $167.92 \pm 91 \mathrm{a}$ & $70 \pm 23 \mathrm{~d}$ & $3.1 \pm 0.28 \mathrm{a}$ & $50.56 \pm 6.76 \mathrm{a}$ \\
Sassuria lappa & $202.92 \pm 6 \mathrm{~b}$ & $15.71 \pm 1.64 \mathrm{~b}$ & $8.77 \pm 3.18 \mathrm{a}$ & $41.67 \pm 0 \mathrm{a}$ \\
Rheum webbanium & $227.08 \pm 2.2 \mathrm{c}$ & $57.14 \pm 2.18 \mathrm{c}$ & $5.1 \pm 1.5 \mathrm{a}$ & $108.33 \pm 1.92 \mathrm{~b}$ \\
Arnebia euchroma & $244.58 \pm 5.07 \mathrm{~d}$ & $0.95 \pm 0.47 \mathrm{a}$ & $17.77 \pm 0.6 \mathrm{~b}$ & $43.89 \pm 4.84 \mathrm{a}$ \\
\hline
\end{tabular}

The value means of three replicates \pm standard error mean. The values followed by different alphabets differ significantly when subjected to Duncan's multiple range test at 0.5 subset

\section{Total Polyphenol, Flavonoid, Flavonol and Proanthocyanidin Content}

The total concentration of polyphenol, flavonol, flavonoid and proanthocyanidin content in methanol extracts of different medicinal herb at a concentration $(100 \mu \mathrm{l} / \mathrm{ml})$ is determined and shown in table 5. The total polyphenol content is expressed as $\mu \mathrm{g}$ of gallic acid equivalent (GAE) per milligram of dry weight. Arnebia euchroma had a total polyphenol content of $244.58 \mu \mathrm{gGAE} / \mathrm{mg}$ followed by Rheum webbanium $(227 \mu \mathrm{gGAE} / \mathrm{mg})$, Sassuria lappa $(202.92 \mu \mathrm{gGAE} / \mathrm{mg})$ and least polyphenol content was Inula racemosa (167.92 $\mu \mathrm{gGAE} / \mathrm{mg})$. The total flavonoid and flavonol content among the various extracts was expressed in the term of quercetin equivalent per milligram of dry weight. Flavonoid content ranged from $(3.1 \mu \mathrm{gQE} / \mathrm{mg}$ to $17.77 \mu \mathrm{gQE} / \mathrm{mg}$ dry) with of different extract and flavonol ranged from $(0.95 \mu \mathrm{gQE} / \mathrm{mg}$ to $70 \mu \mathrm{gQE} / \mathrm{mg})$. Concentration of flavonoid increased by the order Inula racemosa $(3.1 \mu \mathrm{gQE} / \mathrm{mg})<$ Rheum webbanium $(5.1 \mu \mathrm{gQE} / \mathrm{mg})<$

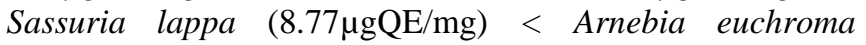
(17.77 $\mu \mathrm{gQE} / \mathrm{mg})$. Similarly, flavonol content increases with the order Arnebia euchroma $(0.95 \mu \mathrm{gQE} / \mathrm{mg})<$ Sassuria lappa $(15.71 \mu \mathrm{gQE} / \mathrm{mg}) \quad<\quad$ Rheum webbanium $(57.14 \mu \mathrm{gQE} / \mathrm{mg})<$ Inula racemosa $(70 \mu \mathrm{gQE} / \mathrm{mg})$. Total proanthocyanidin content was estimated by general procedure. The proanthocyanidin expressed as $\mu \mathrm{g}$ of quercetin equivalent per milligram of dry weight. Proanthocyanidin ranges from $(41.67 \mu \mathrm{gQE} / \mathrm{mg}$ to $108.33 \mu \mathrm{gQE} / \mathrm{mg})$. Rheum webbanium had the highest total proanthocyanidin $(108 \mu \mathrm{gQE} / \mathrm{mg})$ followed by Inula racemosa (50.56 $\mu \mathrm{gQE} / \mathrm{mg}), \quad$ Arnebia euchroma $(43.89 \mu \mathrm{gQE} / \mathrm{mg})$ and the lowest total proanthocyanidin content was in Saussaria lappa $(41.67 \mu \mathrm{gQE} / \mathrm{mg})$.

\section{Conclusion}

In the present study, all the plants showed phenol, flavonoid, flavonol and proanthocyanidin content and exhibit antioxidant activity. All these natural antioxidants from plants extract have pharmaceutical and nutraceuticals importance and they can have significant impact on human health and disease prevention. The present study also supports the scientific basis of use of these plant extracts in traditional health care system. For this reason, further work 
should be done for isolation and identification of the antioxidative components of medicinal plants.

\section{References}

[1] Cook N.C. and Samman, S. (1996), Flavonoidschemistry, metabolism, cardioprotective effects, and dietary sources. Nutritional Biochemistry, Vol. 7 Page No. 66- 76.

[2] Ferrari C.K.B, Torres E.A.F.S.; 2002; Biochemical pharmacology of functional foods and prevention of chronic diseases of aging; Biomedicine \& Pharmacotherapy; 251:258;

[3] Branen, A.L. Toxicology and biochemistry of butylated hydroxyanisole and butylated hydroxytoluene. J. Am. Oil Chem. Soc. 1975, 52, 59-63

[4] Ito, N.; Fukushima, S.; Hagiwara, A.; Shibata, M.; Ogiso, T. Carcinogenicity of butylated hydroxyanisole in F344 rats. J. Natl. Cancer Inst. 1983, 70, 343-352.

[5] Anonymous. The Wealth of India. Vol. IX. New Delhi: National Institute of Science Communication and Resources; 2003. 3-4

[6] Ghorbani, A. (2005) Studies on pharmaceutical ethnobotany in the region of Turkman Sahra, north of Iran. Journal of Ethnopharmacology, 102(1), 58-68.

[7] Liyana-Pathiranan CM, Shahidi F: Antioxidant activity of commercial soft and hard wheat (Triticum aestivum L.) as affected by gastric $\mathrm{pH}$ conditions. J Agric Food Chem 2005, 53:2433-2440.

[8] Teke GN, Lunga PK, Wabo HK, Kuiate JR, Vilarem G, Giacinti G, Kikuchi H, Oshima Y: Antimicrobial and antioxidant properties of methanol extract, fractions and compounds from the stem bark of Entada abyssinica Stend ex A. Satabie. BMC Complement Altern Med 2011, 11:57.

[9] Prakash D, Upadhyay G, Singh BN, Singh HB: Antioxidant and free radical-scavenging activities of seeds and agri-wastes of some varieties of soybean (Glycine max). Food Chem 2007, 104:783-790.

[10] Kroyer GT: Red clover extract as antioxidant active and functional food ingredient. Innov Food Sci Emerg Technol 2004, 5:101-105.

[11]Dajanta K, Apichartsrangkoon A, Chukeatirote E: Antioxidant properties and total phenolics of Thua Nao (a Thai fermented soybean) as affected by Bacillusfermentation. J Microbial Biochem Technol 2011, 3:5659.

[12]Leong LP, Shui G: An investigation of antioxidant capacity of fruits in Singapore markets. Food Chem 2002, 7:69-75.

[13] Re R, Pellegrini N, Proteggente A, Pannala A, Yang M, Rice-Evans C: Antioxidant activity applying an improved ABTS radical cation decolorization assay. Free Radic Biol Med 1999, 26:1231-1237.

[14]Benzie IFF, Strain JJ: The ferric reducing ability of plasma (FRAP) as a measure of "antioxidant power": the FRAP assay. Anal Biochem 1996, 239:70-76.

[15] Gao X, Ohlander M, Jeppsson N, Björk L, Trajkovski $\mathrm{V}$ : Changes in antioxidant effects and their relationship to phytonutrients in fruits of sea buckthorn (Hippophae rhamnoides) during maturation. J Agric Food Chem 2000, 48:1485-1490.
[16] Ordon Ez AAL, Gomez JD, Vattuone MA, Isla MI: Antioxidant activities of Sechium edule (Jacq.) swart extracts. Food Chem 2006, 97:452-458.

[17] Kumaran A, Karunakaran RJ: In vitro antioxidant activities of methanol extracts of Phyllanthus species from India. LWT 2007, 40:344-352.

[18] Price ML, Van Scoyoc S, Butler LG: A critical evaluation of the vanillin reaction as an essay for tannin in sorghum grain. J Agric Food Chem 1978, 25:12141218.

[19] Oktay M. Gulein I, Kufrevioglu I. Determination of invitro antioxidant ativity of fennel (Foeniculumvalgare) seed extracs. LabensonWiss V. Technol. 2003; 36: 26371

[20] Aydemir T, Becerik S (2011). Phenolic content and antioxidant activity of different extracts from Ocimum basilicum, Apium graveolens and Lepidium sativum seeds. J. Food Biochem., 35: 62-79.

[21]Elmastas M., Gulcin I., Isildak O., Kufrevioglu O.I. Ibaoglu K., Aboul-Enein H.Y. Radical scavenging activity and antioxidant capacity of Bay leaf extracts. Journal of Iranian Chemical Society. 2006; 3(3): 258266

\section{Author Profile}

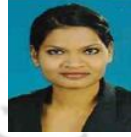

Suman Tiga is Scientist, M.Sc., Defence Institute of High Altitude Research

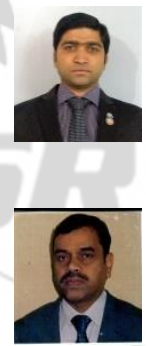

Prabhu Prasad Sarangi is Scientist, M.Sc., Defence Institute of High Altitude Research

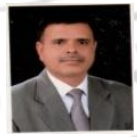

Dr Bhuvnesh kumar is Scientist, M.V.Sc, PhD Defence Institute of High Altitude Research 